We are extremely grateful to the headmaster, staff, and pupils of the school, and to the Inner London Education Authority, for allowing the survey to take place.

\section{References}

Department of Education and Science (1966). Nutritional Standard of School Dinners. Circular 3/66. London, H.M.S.O.
Department of Health and Social Security (1969). Recommended Intakes of Nutrients for the United Kingdom. Report No. 120. London, H.M.S.O. McCance, R. A., and Widdowson, E. M. (1960). Composition of Foods. Medical Research Council. Special Report Series, No. 297.

Miller, D. S., and Payne, P. R. (1959). British fournal of Nutrition, 13, 501. Miller, D. S., and Mumford, P. (1970). Proceedings of Nutrition Society, 29, 116. Bender, A. E., Magee, P., and Nash, A. H. (1972). British Medical fournal,

Mortimer, P. M. (1968). Proceedings of the Nutrition Society, 27, 29.

Hampton, M. C., Huenemann, R. L., Shapiro, L. R., and Mitchell, B. W. (1967). Fournal of the American Dietetic Association, 50, 385.

\title{
Effects of Oestrogen on Urinary Thyroxine Excretion
}

\author{
VIVIAN CHAN， G. M. BESSER， J. LANDON
}

British Medical fournal, 1972, 4, 699-701

\begin{abstract}
Summary
The day to day variation and the effects of oestrogen on the urinary excretion of thyroxine ( $T-4)$ were studied in euthyroid women and men. Serial urinary $T-4$ values over a period of 28 consecutive days were found to lie within relatively narrow limits except for a transient increase during menstruation in women. During oestrogen therapy urinary $T-4$ was unchanged, but an appreciable rise was seen after stopping oral ovulation inhibitors in women. A similar effect was seen in men after three days' treatment with $20 \mu \mathrm{g} /$ day of ethinyloestradiol. The increased urinary $T-4$ excretion on oestrogen withdrawal reached a maximum in one to three days. This response contrasted with that produced by phenytoin, a drug known to bind to thyroxine binding globulin, and which resulted in increased urinary $T-4$ excretion during the period that it was being administered.
\end{abstract}

\section{Introduction}

Increased levels of oestrogen in the blood, whether of exogenous or endogenous origin, have profound effects on thyroid function tests. Heinemann et al. (1948) were the first to report that serum protein bound iodine (P.B.I.) increased in pregnancy and Engstrom and his colleagues (1952) found that this could be induced in non-pregnant women by oestrogen administration. The rise in P.B.I. levels is accompanied by a shift in the uptake of triiodothyronine ( $\mathrm{T}-3)$ by the patient's serum or red cells into the hypothyroid range (Hollander et al., 1963; Winikoff and Taylor, 1966). Both effects can be attributed to an increase in certain serum proteins and their capacity to bind thyroid hormones (Dowling et al., 1956; Engbring and Engstrom, 1959; Tata, 1960; Florsheim and Faircloth, 1964). Clark and Horn (1965) introduced the free thyroxine (T-4) index, calculated from the P.B.I. and T-3 uptake results, to correct for changes in these serum levels. Circulating T-3 levels also increase during pregnancy (Hotelling and Sherwood, 1971) despite the fact that it is less avidly bound by thyroxine binding proteins as compared with T-4. Other thyroid parameters which are influenced by the administration of oral ovulation inhibitors include the

St. Bartholomew's Hospital, London E.C.1

VIVIAN CHAN, M.SC., Biochemist, Department of Chemical Pathology G. M. BESSER, M.D., M.R.C.P., Senior Lecturer in Endocrinology, The Medical Professorial Unit

J. LANDON, M.D., M.R.C.P., Professor of Chemical Pathology secretion of thyroid stimulating hormone (Fisher and D'angelo, 1971; Galton, 1971), thyroidal 131I uptake (Kennedy et al., 1964; Boccabella and Alger, 1964), the T-4 half-life (Engbring and Engstrom, 1959), and circulating free T-4 concentration (Arango et al., 1968; Rosenbaum et al., 1968; Fang and Selenkow, 1970; Malkasian and Mayberry, 1970). The latter is of particular interest as it is regarded as the biologically active fraction, and thus reflects the true thyroid status of the individual.

The present study was undertaken to assess the effects of oestrogen on urinary T-4 excretion, as it has been suggested that the latter relates directly to the serum free T-4 concentration (Chan and Landon, 1972). Serial urinary T-4 values over a period of 28 days were studied in euthyroid men and women, and compared with those in women receiving oral contraceptives. The effects of ethinyl oestradiol and of phenytoin administration on urinaty $\mathrm{T}-4$ excretion in healthy euthyroid men were also investigated.

\section{Subjects and Methods}

A total of 66 volunteers were studied, comprising 34 healthy ambulant subjects, 20 euthyroid inpatients, and 12 women receiving oral ovulation inhibitors.

Urine was collected from each subject over a single 24-hour period, together with a $12-\mathrm{ml}$ blood sample. Further urine collections were made for 28 consecutive days in three groups of healthy volunteers aged 20 to 30 . The groups comprised five men, five women, and five women who had been receiving oral ovulation inhibitors containing either $50 \mu \mathrm{g}$ per tablet of ethinyloestradiol or mestranol for periods of four to 36 months.

A further nine healthy euthyroid male volunteers were studied to determine the effect of ethinyloestradiol on urinary T-4, serum total T-4, and T-3 uptake. Samples were collected for a three to five-day control period during the three days they received ethinyloestradiol ( $20 \mu \mathrm{g}$ daily) and for four to six days afterwards.

The effects of phenytoin on thyroid function were also studied in one healthy euthyroid man. Samples were collected for a three-day control period during the four days of phenytoin medication and for a further two days after cessation of therapy.

Blood samples were separated within two hours of venepuncture and the serum stored at $-20^{\circ} \mathrm{C}$ until required for assay. The determination of serum P.B.I. by a Technicon automated method, and a total T-4 and T-3 uptake by a Sephadex equilibration technique, was performed as described previously (Chan and Landon, 1972; Chan et al., 1972).

Urinary T-4 estimations were made using duplicate 3-ml aliquots of urine according to the method described previously (Chan and Landon, 1972). This involved acidification of the urine sample, solvent extraction, and determination of T-4 content of the extract by saturation analysis. 


\section{Results}

The results of single 24-hour urinary T-4 determinations and of other in-vitro tests of thyroid function in control subjects and in women receiving oral contraceptives are compared in the Table. Urine T-4 values in 54 euthyroid subjects ranged from

In-vitro Thyroid Function Tests (mean \pm S.E.) and Correlation Between Them

\begin{tabular}{|c|c|c|c|}
\hline & $\underset{(n=54)}{\text { Euthyroid }}$ & $\begin{array}{l}\text { Women on Oral } \\
\text { Ovulation Inhibitors } \\
(n=12)\end{array}$ & $\mathbf{P}^{*}$ \\
\hline $\begin{array}{l}\text { Urinary T-4 }(\mu \mathrm{g} / 24 \mathrm{hr}) \\
\text { Serum total T-4 }(\mu \mathrm{g} / 100 \mathrm{ml}) \ldots \\
\text { Serum T-3 uptake }(\%) \\
\text { Serum P.B.I. }(\mu \mathrm{g} / 100 \mathrm{ml}) \quad \ldots\end{array}$ & $\begin{array}{r}8 \cdot 0 \pm 0.29 \\
9 \cdot 1 \pm 0.23 \\
105.4 \pm 0.89 \\
6.2 \pm 0.16\end{array}$ & $\begin{array}{r}7.9 \pm 0.52 \\
11.8 \pm 0.72 \\
123.9 \pm 1.91 \\
8.2 \pm 0.52\end{array}$ & $\begin{array}{l}\text { N.S. } \\
<0.001 \\
<0.001 \\
<0.001\end{array}$ \\
\hline
\end{tabular}

* Based on Student's $t$ test (2-tailed).

N.S. = Not significant.

4.3-12.7 $\mu \mathrm{g} / 24 \mathrm{hr}$. The 12 women who were taking oral ovulation inhibitors all had urine $T-4$ values within this range, and the mean levels of the two groups were not significantly different. In contrast, mean serum total T-4, P.B.I., and T-3 uptake values were all significantly different $(P<0.001)$ from the control values.

The mean serial urinary T-4 values over a 28 -day period for each group are shown in Fig. 1. In the euthyroid male group

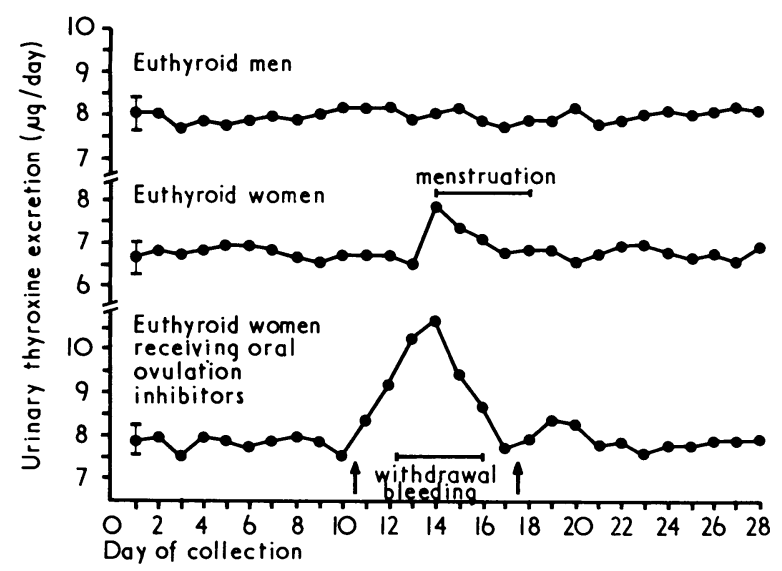

FIG. 1-Mean day to day variation in urinary thyroxine excretion in three groups of healthy volunteers, comprising five euthyroid men, five euthyroid women, and five euthyroid women receiving oral ovulation inhibitors. ovulation inhibitors. Standard deviations of means are shown.

there was no significant variation in $\mathrm{T}-4$ excretion over the 28 days, and values for each subject fell within relatively narrow absolute limits $( \pm 0.8 \mu \mathrm{g} / 24 \mathrm{hr}$ of the subject's mean). Findings were similar in the group of euthyroid women, except that there was a transient rise during menstruation, ranging from 1 to $2 \mu \mathrm{g} / 24 \mathrm{hr}$. Urinary T-4 values in women receiving oral ovulation inhibitors showed an appreciable increase above basal levels after withdrawal of oestrogen/progestogen, ranging from 2 to $4.3 \mu \mathrm{g} / 24 \mathrm{hr}$. Their T-4 excretion returned to basal levels within five days and was not significantly influenced by resumption of oral contraceptives. The difference between the mean urinary $T-4$ value after oestrogen withdrawal as compared with that during the remainder of the cycle was statistically significant $(P<0.01)$.

The effect of ethinyloestradiol administration in a group of nine healthy euthyroid men is shown in Fig. 2. Urinary T-4 excretion remained constant before and during therapy, but each subject showed a large increase above control levels after oestrogen withdrawal. The rise was transient, reaching a maximum (ranging from 3.1 to $8.6 \mu \mathrm{g} / 24 \mathrm{hr}$. above basal levels) within one to three days and then returning to normal. No significant change was noted in the mean serum total T-4 and T-3 uptake during and after oestrogen therapy.
The effect of phenytoin medication in one euthyroid man is shown in Fig. 3. Urinary T-4 excretion increased at the start of therapy and decreased on stopping. No appreciable changes were observed in either serum total T-4 or T-3 uptake throughout the duration of the study.

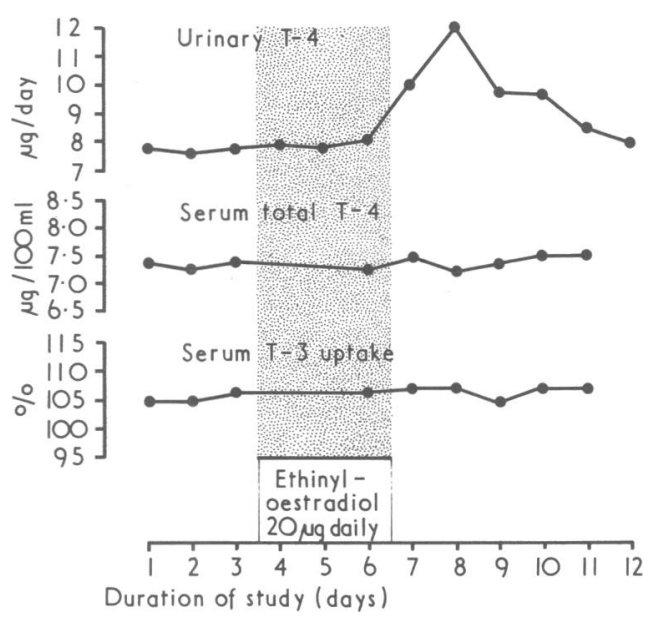

FIG. 2-Effect of ethinyloestradiol on thyroid function tests in healthy euthyroid men. Data represent mean tests in healthy euthyroid
values in nine subjects.

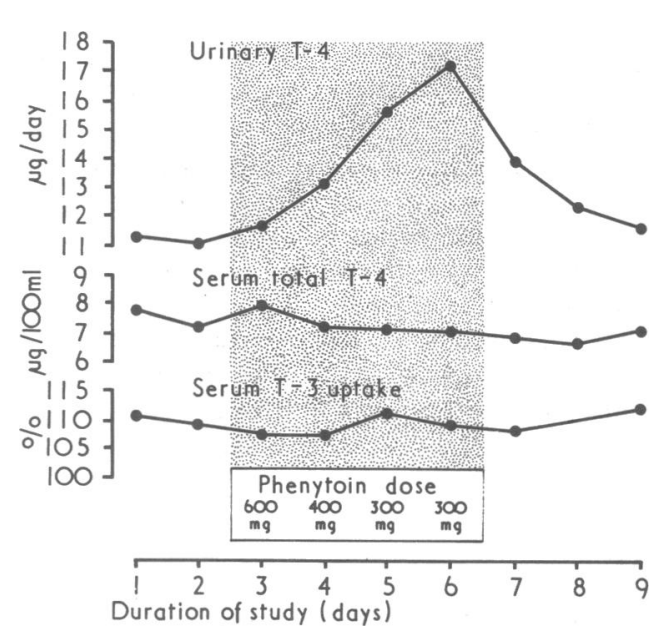

FIG. 3-Effect of phenytoin on thyroid function tests in one healthy euthyroid man.

\section{Discussion}

It has previously been suggested that urinary $\mathrm{T}-4$ excretion is directly related to serum non-protein bound (free) T-4 concentration (Chan and Landon 1972). The normal urinary values found in women during administration of ovulation inhibitors or oestrogens alone support the findings of Arango et al. (1968), Rosenbaum et al. (1968), and Fang et al. (1970), that circulating free $\mathrm{T}-4$ levels are normal during oestrogen therapy.

The transient increase in urinary T-4 after oestradiol withdrawal contrasts with the immediate increase observed on the initiation of phenytoin therapy. It is probable that phenytoin displaces $\mathrm{T}-4$ from serum protein binding sites, resulting in an increased circulating free hormone concentration, and this is reflected in an increased urinary T-4 excretion. This is not an artefact due to the presence of phenytoin or its metabolites in the urine since we have shown that there are insufficient quantities extracted from the urine to interfere with the T-4 determination in the in-vitro assay system.

A decrease in T-4 binding capacity of serum may account for the pronounced increase in urinary $T-4$ observed during oestrogen withdrawal both in women on oral contraceptives and in men given ethinyloestradiol. Since this effect was 
observed after only three days treatment with a small dose of ethinyloestradiol it is possible that this may reflect an alteration in binding constant of thyroxine binding proteins rather than a quantitative change. The rapidity with which urinary T-4 returns to basal levels is probably due to the negative feedback control mechanism of the pituitary-thyroid axis whereby circulating levels of the free T-4 influence the release of thyrotrophin. Other possible explanations for these findings include alteration of the hepatic metabolism of $\mathrm{T}-4$ after oestrogen withdrawal, which might account for, or contribute to, the increase in urinary $\mathrm{T}-4$ excretion.

A short course of treatment with ethinyloestradiol did not produce any significant effect on the routine serum thyroid function tests used, although pronounced changes in urinary T-4 excretion were observed. This reflects the sensitivity of the urine T-4 assay. Continued investigation of this thyroidovarian inter-relation is required. Studies of the effects of increased circulating free $\mathrm{T}-4$ on sex hormone binding capacity and of oestrogen therapy on serum thyroid stimulating hormone levels may help in this respect.

We thank Dr. A. Richens for his help in the phenytoin studies, and the Board of Governors, St. Bartholomew's Hospital, for financial support for this project.

Requests for reprints should be sent to: Professor J. Landon, St. Bartholomew's Hospital, London EC1A 7BE.

\section{References}

Arango, G., Mayberry, W. E., Hockert, T. J., and Elveback, L. R. (1968). Proceedings of the Staff Meetings of the Mayo Clinic, 43, 503.

Boccabella, A. V., and Alger, E. A. (1964). Endocrinology, 74, 680.

Chan, V., and Landon, J. (1972). L Lancet, $1,4$.

Chan, V., McAlister, J., and Landon, J. (1972). Fournal of Clinical Pathology, $25,30$.

Clark, F., and Horn, D. B. (1965). Fournal of Clinical Endocrinology and Metabolism, 25, 39.

Dowling, J. T., Freinkel, N., and Ingbar, S. H. (1956). Fournal of Clinical Endocrinology and Metabolism, 16, 1491

Engbring, N. H., and Engstrom, W. W. (1959). Fournal of Clinical Endocrinology and Metabolism, 19, 783.

Engstrom, W. W., Markardt, B., and Leibman, A. (1952). Proceedings of the Society for Experimental Biology and Medicine, 81, 582 .

Fang, V. S., and Selenkow, H. A. (1970). Clinical Chemistry, 16, 185.

Fisher, J. S., and D'angelo, S. A. (1971). Endocrinology, 88, 687.

Florsheim, W. H., and Faircloth, M. A. (1964). Proceedings of the Society for Experimental Biology and Medicine, 117, 56.

Galton, V. A. (1971). Endocrinology, 88, 976.

Heinemann, M., Johnson, C. E., and Man, E. B. (1948). fournal of Clinical Investigation, 27, 91.

Hollander, C. S., Garcia, A. M., Sturgis, S. H., and Selenkow, H. A. (1963). New England fournal of Medicine, 269, 501 .

Hotelling, D. R., and Sherwood, L. M. (1971). Fournal of Clinical Endocrinology and Metabolism, 33, 783.

Kennedy, G. C., Salaman, D. F., and Hague, P. (1964). Fournal of Endocrinology, 29, 97.

Malkasian, G. D., and Mayberry, W. E. (1970). American fournal of Obstetrics and Gynecology, 108, 1234.

Rosenbaum, J. M., Kreig, A. F., Henry, J. B., Mozley, J. M., and McAfee, J. G. (1968). American fournal of Clinical Pathology, 50, 336.

Tata, J. R. (1960). British Medical Bulletin, 16, 142.

Winikoff, D., and Taylor, K. (1966). Medical fournal of Australia, 2, 108.

\title{
Prevalence of Antibody to Current Influenza Viruses and Effect of Vaccination on Antibody Response
}

\author{
MARGUERITE S. PEREIRA， PRATIMA CHAKRAVERTY， G. C. SCHILD， MARION T. COLEMAN, \\ W. R. DOWDLE
}

British Medical fournal, 1972, 4, 701-703

\section{Summary}

The extent of antibody to the influenza virus $A / H o n g$ Kong/68 (H3N2) after four years of prevalence was investigated in Britain and in the U.S.A. The results indicated a high incidence in both populations. The prevalence of antibody to a variant $A /$ England/42/72 (H3N2) which has been causing epidemics of influenza in the southern hemisphere during the middle months of 1972 was also investigated. The differences reflect the shift in antigenic content of this variant, and although the overall proportion of the sera with antibody at $\geqslant 1 / 40$ was $37 \%$, some age groups had an incidence of only $20 \%$ or less with antibody at this level. A commercial inactivated $A / H o n g$ Kong/68 influenza vaccine was given to a group of volunteers in Britain to see how effective it might be in stimulating antibody to the variant $A /$ England $/ 42 / 72$. The antibody responses were better than expected from ear-

\footnotetext{
Virus Reference Laboratory, Central Public Health Laboratory, London NW9 5HT

MARGUERITE S. PEREIRA, M.D., Director of Virus Reference Laboratory

PRATIMA CHAKRAVERTY, B.SC., M.PHIL., Member of Scientific Staff

W.H.O. World Influenza Centre, National Institute for Medical Research, London NW7 1AA

G. C. SCHILD, B.SC., PH.D. Director of World Influenza Centre

W.H.O. International Influenza Centre for the Americas, Centre for Disease Control, Health Services and Mental Health Administration, Public Health Service, U.S. Department of

Health, Education, and Welfare, Atlanta, Georgia 30333, U.S.A. MARION T. COLEMAN, PH.D., Member of Scientific Staff W. R. DOWDLE, PH.D., Member of Scientific Staff
}

lier vaccine studies, and $63 \%$ of the vaccinees developed antibody to the $A /$ England/42/72 to levels thought likely to be protective. This suggested that until a vaccine made with the variant $A /$ England $/ 42 / 72$ becomes available the present $A / H o n g$ Kong/68 vaccine would be of use to protect those at special risk this winter.

\section{Introduction}

The appearance of the influenza virus A/Hong Kong/68 (H3N2) in 1968 was followed by extensive winter epidemics in which in Britain about two-thirds of the population acquired antibody to this virus (Miller et al., 1971). The winter of 1970-1 was notable in Britain for the absence of epidemiological indices of influenza prevalence, with no increase in morbidity or mortality rates. This would have been regarded as a non-influenza winter, but it was apparent to laboratory workers that the virus was, none the less, circulating to a small extent, since 50 strains of virus were isolated. During the winter of 1971-2 the virus reappeared, and over 700 strains were isolated from cases all over the country. Because of the extended period during which this occurred only small changes resulted in the epidemiological indices. It seemed probable that after these further two years most people in Britain would have antibody to the A/Hong Kong/68 virus and there were likely to be insufficient susceptibles to allow further epidemics of any size to occur.

In the autumn of 1972 epidemics of influenza were reported in the southern hemisphere associated with strains which were significantly different from the A/Hong Kong/ 68 virus. These strains were found to be similar to one (numbered A/England/42/ 72) that had been isolated from a case of influenza in January 1972 in England and which was the only strain of 752 examined that winter to show altered antigenic characteristics (Schild et al., 1972). It was realized that if this variant strain spread in 